University of Nebraska - Lincoln

DigitalCommons@University of Nebraska - Lincoln

2003

\title{
A Comparative Analysis of Social Play in Birds
}

Judy Diamond

University of Nebraska - Lincoln, jdiamond1@unl.edu

Alan B. Bond

University of Nebraska - Lincoln, abond1@unl.edu

Follow this and additional works at: https://digitalcommons.unl.edu/bioscibehavior

Part of the Behavior and Ethology Commons

Diamond, Judy and Bond, Alan B., "A Comparative Analysis of Social Play in Birds" (2003). Papers in Behavior and Biological Sciences. 35.

https://digitalcommons.unl.edu/bioscibehavior/35

This Article is brought to you for free and open access by the Papers in the Biological Sciences at DigitalCommons@University of Nebraska - Lincoln. It has been accepted for inclusion in Papers in Behavior and Biological Sciences by an authorized administrator of DigitalCommons@University of Nebraska - Lincoln. 


\title{
A Comparative Analysis of Social Play in Birds
}

\author{
Judy Diamond \\ University of Nebraska State Museum, Lincoln, Nebraska, 68588 USA
}

\author{
Alan B. Bond \\ School of Biological Sciences, \\ University of Nebraska-Lincoln, Lincoln, Nebraska, 68588 USA
}

Corresponding author - J. Diamond, jdiamond@unl.edu

\begin{abstract}
Summary
Although social play is broadly distributed among mammals, it is infrequently encountered in other vertebrate taxa. It is, however, displayed in a fully realized and complex form in several groups of birds. Unambiguous accounts of social play have been recorded from thirteen species of parrots, seven species of corvids, and several hornbills and Eurasian babblers. We conducted an analysis of the avian play literature, testing for differences between avian taxa, as well as for correlations between play complexity, brain size, and age of first reproduction. Corvids were far more likely to show social object play than parrots. Corvids, parrots, and hornbills had larger relative brain sizes than would be predicted from a class-level allometric regression, but brain size was not associated with the complexity of social play among genera within taxa. Play complexity within parrots and corvids was, however, significantly associated with the age of first reproduction. The likelihood of complex social play appears to increase when delayed reproduction is accompanied by persisting relationships between adults and post-fledging juveniles. The adaptive significance of social play in birds thus offers intriguing parallels to similar analyses in mammals.
\end{abstract}

This work was supported in part by the National Geographic Society, the University of Nebraska State Museum, and the University of Nebraska School of Biological Sciences. The authors thank P. Sweet from the American Museum of National History, W. Longmore of Museum Victoria at Melbourne, and Dr. R. Mulder and I. Woxvold, Department of Zoology, University of Melbourne, who generously provided us with apostlebird weights. Dr. G. Paz-y-Miño C. and two anonymous reviewers for Behaviour provided us with thoughtful comments on an earlier version of this manuscript. 


\section{Introduction}

Social play is pervasive among juvenile mammals, forming a central element in the social behavior of even relatively solitary species (Bekoff and Byers, 1998). Birds are also known to play socially, but very few avian taxa exhibit the full range of play behaviors, from play chases to complex reciprocal object play (Fagen, 1981; Ortega and Bekoff, 1987). Because birds and mammals share only a very remote evolutionary history, it seems likely that social play has evolved convergently in these groups, with possibly several independent origins. A close comparative analysis of social play in birds may, therefore, cast light on the selective factors that have encouraged its development, forming a parallel to similar studies of social play in mammals (Iwaniuk et al., 2001).

Play behavior has been recognized in birds for over a century (Groos, 1898) and has since been described in ten orders of birds (Fagen, 1981; Ortega and Bekoff, 1987; adjusted to accord with Monroe and Sibley, 1993). Examples of avian social play, however, are generally uncommon (Skeate, 1985). Most instances of avian play behavior described in the literature are essentially solitary, either locomotory play (e.g. aerobatic flight of raptors, gulls and frigate birds in Stonehouse and Stonehouse, 1963; Simmons and Mendelsohn, 1993; Pandolfi, 1996; Gamble and Cristol, 2002) or object play, in the form of repeated manipulation of inappropriate items (e.g. "play caching" by pinyon jays, Gymnorhinus cyanocephalus, in Marzluff and Balda, 1992 and magpies, Pica pica, in Deckert, 1991; tossing stones by warblers, Sylvia borin in Sauer, 1956; bouncing on food by motmots, Eumomota superciliosa, in Smith, 1977).

Social play is prevalent in many groups of mammals (Brereton, 1971; Ewer, 1973; Ficken, 1977; Fagen, 1981; Barber, 1991; Bekoff and Allen, 1998). Some forms of play have also been described in reptiles or even fish (Fagen, 1981; Burghardt, 1998), but these species do not display the robust, reciprocal social play that is exhibited in its most elaborate forms in wolves, chimpanzees and humans (Beach, 1945; Mech, 1970; Fossey, 1978; Garvey, 1990; Parker and Milbrath, 1994; Power, 2000).

Parrots and corvids are generally considered to exhibit more extensive social play than other birds (Ficken, 1977; Fagen, 1981; Iwaniuk et al., 2001). Within these groups, the most frequently cited exemplars of avian play have been keas (Nestor notabilis) and ravens (Corvus corax) (Fagen, 1981; Ortega and Bekoff, 1987; Heinrich and Smolker, 1998; Diamond and Bond, 1999). Play in these two species is certainly vigor- 
ous, complex, and socially reciprocal and may well provide an equivalent to the social play of canids and higher primates (Fagen, 1981). How common social play may be among birds is difficult to assess, however. Descriptions of ostensible avian play in the literature are often too brief and anecdotal to categorize (Ficken, 1977). In fact, detailed studies of play in birds have focused mainly on keas, ravens, and a series of studies of the Australasian magpie (Gymnorhina tibicen; Pellis, 1981a, 1982).

Definitions of play behavior have been discussed extensively in the literature (e.g. Bekoff, 1976; Fagen, 1981; Bekoff and Byers, 1981; Bekoff, 1984; Barber, 1991; Bekoff and Allen, 1998; Power, 2000; Spinka et al., 2001; Burghardt, 2001). This study focuses on social play, that is, play behavior that involves at least two individuals who interact with and respond to each other and are thus capable of exchanging information (Bekoff, 1974; Ficken, 1977; Fagen, 1981). Social play in birds shares many characteristics with social play in mammals. For example, it generally incorporates actions from a variety of contexts into labile temporal sequences and the actions are often repeated by mutual initiative. Social play most commonly involves juveniles (Power, 2000), but different kinds of social play may have different players and developmental time courses (Bekoff, 1974; Fagen, 1981; Simmons and Mendelsohn, 1993). Social play lacks consummatory behaviors (Lorenz, 1956), so that interactions are not resolved, but rather are repeated with the partners alternating roles, until they are distracted by other stimuli.

Behavioral evolution is most readily addressed through comparative studies, which aid in establishing functional associations between behavior and morphology or ecology (Lorenz, 1956; Bekoff et al., 1981; Felsenstein, 1985; Harvey \& Pagel, 1991; Bond and Kamil, 2002; Bond et al., 2003). Studies of play in mammals have commonly used a comparative approach, but systematic comparative studies of play in birds are rare (Ortega and Bekoff, 1987; Fagen, 1981; Burghardt, 1998). Surveys of avian play have suggested that it is associated with altricial development (Ortega and Bekoff, 1987; Power, 2000), with larger relative brain size (Ortega and Bekoff, 1987; Heinrich and Smolker, 1998), and with higher degrees of sociality (Skutch, 1987; Collar, 1997). In this article, we describe the form and incidence of social play in the most unambiguous accounts in the avian literature and relate the similarities and differences to aspects of the species' taxonomy, morphology, and life history. 


\section{A survey of avian social play}

To place avian play in a broader systematic context, we categorized instances of social play recorded in the literature. Our criteria were derived from classification systems proposed over the last forty years (Ficken, 1977; Fagen, 1981; Bekoff, 1984, 1995; Ortega and Bekoff, 1987; Pellis and Pellis, 1996; reviewed in Power, 2000). Conspecifics, in our view, engage in social play when they respond to one another, not just when they act in each other's presence. Social play may include various components that are facilitated (e.g. Ashmole and Tovar, 1968; Negro et al., 1996; Gamble and Cristol, 2002), but facilitation alone does not constitute sufficient evidence for social play. Our approach thus contrasts with that of Harvey et al. (2002), who divided play in captive Hawaiian crows (Corvus hawaiiensis) into solo and social play based on the proximity of the mate regardless of whether or not the birds were responding to each other.

We distinguished among four empirically separable categories of social play: play chasing, play fighting, play invitations, and social object play. Play chasing occurs when one bird follows another in flight or on the ground. It can be distinguished from flocking or other facilitative movements by the absence of consummatory behavior at the end of the chase and by the repeated exchange of roles of pursuer and pursued. Play fighting involves action patterns derived from agonistic behavior, but which are performed in ways that minimize injurious consequences. Play fighting also includes only a limited portion of the aggressive repertoire of the species. Play invitations are action patterns that occur predominately in the context of social play. They occur at the onset of a play interaction or after a brief interruption, and they are followed by play fighting or social object play. Social object play occurs when two or more individuals engage in repeated interaction with one or more inanimate objects in the environment without subsequent consummatory behavior. The best evidence of social object play is provided by contests over items that cannot be otherwise turned to useful purposes. Role reversals are common in social object play, and the interaction often ends with the contested item simply being discarded.

Our initial literature review provided examples of social play in eight families of birds (Table 1). Accounts of play chasing, particularly if they were contextually ambiguous and unaccompanied by other forms of social play, were subsequently excluded from our analysis (e.g. Pygoscelis adeliae, Muller-Schwarze, 1978; Tauraco fischeri, Moreau, 1938; 
Table 1. Avian social play

\begin{tabular}{lcll}
\hline Species & $\begin{array}{l}\text { Play Play } \\
\text { chase fight- invi- } \\
\text { ing tation }\end{array}$ & $\begin{array}{l}\text { Social } \\
\text { object }\end{array}$ & References \\
$(\mathrm{c}=$ captive; $\mathrm{w}=$ wild $)$
\end{tabular}

\section{Psittaciformes}

\section{PSITTACIDAE}

\begin{tabular}{|c|c|c|c|c|c|}
\hline Chalcopsitta sintillata & $X$ & & & & Collar, 1997 (w) \\
\hline Pseudeos fuscata & $X$ & & & & Collar, 1997 (w) \\
\hline Eolophus roseicapillus & $x$ & & & & Rowley, 1990, 1997 (w) \\
\hline Nestor notabilis & $x$ & $x$ & $x$ & $x$ & $\begin{array}{l}\text { Diamond and Bond, } 1999 \text { (w); } \\
\text { Keller, } 1975 \text { (c); Potts, } 1969 \text { (c) }\end{array}$ \\
\hline Nestor meridionalis & $x$ & $x$ & $x$ & & $\begin{array}{l}\text { Diamond and Bond, } 2002(w) \text {; } \\
\text { Jackson, 1963b (w) }\end{array}$ \\
\hline Psephotus chrysopterygius & $x$ & & & & Collar, 1997 (w) \\
\hline Melopsittacus undulatus & $x$ & $x$ & & & Engesser, 1977 (c) \\
\hline Strigops habroptilus & & $X$ & $x$ & & Elliott, 2002 pers. com. (w) \\
\hline Anodorhynchus hyacinthinus & & $x$ & $x$ & & Hick, 1962 (c) \\
\hline Ara chloropterus & $x$ & $x$ & $x$ & & Deckert, 1991 (c); Hick, 1962 (c) \\
\hline Myiopsitta monachus & $x$ & & & & Shepherd, 1968 (c) \\
\hline Forpus conspicillatus & $x$ & & & & $\begin{array}{l}\text { Garnetzke-Stollmann \& } \\
\text { Franck, } 1991 \text { (c) }\end{array}$ \\
\hline Amazona albifrons & $x$ & $x$ & $\mathrm{X}$ & & $\begin{array}{l}\text { Levinson, } 1980(\mathrm{w}, \mathrm{c}) \\
\text { Skeate, } 1985(\mathrm{c})\end{array}$ \\
\hline
\end{tabular}

\section{Bucerotiformes}

\section{BUCEROTIDAE}

Ceratogymna brevis

\section{BUCORVIDAE}

Bucorvus leadbeateri

$$
\text { X X }
$$

X Kemp, 2001 (w);

Kemp and Kemp, 1980 (w)

\section{Passeriformes}

\section{CORVIDAE}

\begin{tabular}{|c|c|c|c|c|c|}
\hline Corcorax malanorhamphos & $x$ & $x$ & & $x$ & $\begin{array}{l}\text { Chisholm, } 1958(\mathrm{w}) \text {; } \\
\text { Heinsohn, } 2003 \text { pers. com. (w) }\end{array}$ \\
\hline Struthidea cinerea & $X$ & $x$ & $X$ & $x$ & $\begin{array}{l}\text { Baldwin, } 1974(w) ; \\
\text { Chisholm, } 1958(w)\end{array}$ \\
\hline Pica pica & $x$ & & & & Deckert, 1991 (c) \\
\hline
\end{tabular}


Table 1. Avian social play (continued)

\begin{tabular}{|c|c|c|c|c|c|}
\hline Species & & $\begin{array}{l}\text { y Play } \\
\text { Ise fight- } \\
\text { ing }\end{array}$ & $\begin{array}{l}\text { Play } \\
\text { invi- } \\
\text { tation }\end{array}$ & $\begin{array}{l}\text { Social } \\
\text { object } \\
\text { play }\end{array}$ & $\begin{array}{l}\text { References } \\
(c=\text { captive; } w=\text { wild })\end{array}$ \\
\hline Corvus brachyrhyncos & & & & $x$ & Kilham, 1989, 1984 (w) \\
\hline Corvus corax & $x$ & $x$ & & $x$ & $\begin{array}{l}\text { Eklow, } 1988 \text { (w); Gwinner, } 1966 \text { (c); } \\
\text { Heinrich and Smolker, } 1998 \text { (w) }\end{array}$ \\
\hline Corvus albicollis & & & & $x$ & Moreau and Moreau, $1944(w)$ \\
\hline Gymnorhina tibicen & $x$ & $x$ & $x$ & $x$ & Pellis, 1981a, b (w) \\
\hline \multicolumn{6}{|l|}{ SYLVIIDAE } \\
\hline Turdoides malcolmi & & $x$ & & & $\begin{array}{l}\text { Gaston, 1977(w); } \\
\text { Hutson, } 1954(w)\end{array}$ \\
\hline Turdoides squamiceps & $x$ & $x$ & & $x$ & Posis, 1984 (w); Zahavi, 1990 (w) \\
\hline Turdoides striatus & $x$ & $x$ & & & Gaston, $1977(w)$ \\
\hline
\end{tabular}

Circus pygargus, Pandolfi, 1996; Gypaetus barbatus, Blumstein, 1990; Dendrocopos villosus and D. pubescens, Kilham, 1974). This was a particular problem with accounts of play chasing in raptors, because we could not distinguish observations of social play from facilitated flight movements (Simmons and Mendelsohn, 1993). The final data set thus consisted of 25 species in five families of parrots, hornbills, Eurasian babblers, and corvids (Table 1 ).

\section{Social play in the Psittacidae}

Most of the accounts of social play in our survey were recorded from parrots - thirteen species from this family alone (Table 1). In seven of these, social play consists solely of play chases and/or play fighting. For example, Collar (1997) describes small nursery flocks of newly fledged golden-shouldered parrots Psephotus chrysopterygius engaging "in wild careering flights" in and out of the trees. Similar behaviors have been seen in galahs (Eolophus roseicapillus), monk parakeets (Myiopsitta monachus), yellow-streaked lories (Chalcopsitta sintillata), dusky lories (Pseudeos fuscata), spectacled parrotlets (Forpus conspicillatus), and budgerigars (Melopsittacus undulatus) (Shepherd, 1968; Engesser, 1977; Garnetzke-Stollmann and Franck, 1991; Rowley, 1997; Collar, 1997). 
Parrots that play fight usually "fence" or feint with the bill, push with the feet, or bite the feet or feathers of the play partner. Budgerigars, for example, try to bite their play partner somewhere on the body, usually in the feathers or the feet. The play partner parries with its beak, sometimes while producing soft croaking sounds, and the behavior often develops into a repeated beak duel, initiated by first one partner and then the other (Engesser, 1977). That such actions are play, rather than serious aggression, is suggested by the fact that they are performed slowly, that the interactions are reciprocally initiated, and that there is no apparent resolution, no winners or losers in the contests. Play fighting in white-fronted parrots (Amazona albifrons) is also readily distinguishable from actual aggressive interactions (Skeate, 1985). During aggressive interactions, these birds direct bill-gapes and bill-lunges at the opposing bird's head, but during play bouts, play-biting is directed mainly at the feet and toes of the other bird.

Play fights in keas and kakas (Nestor meridionalis) show many similar action patterns, but the event sequences appear to be generally more complex in keas (Diamond and Bond, 1999). Kakas engage in long, repetitive bouts in which one individual rolls over on its back while the partner jumps on its stomach, with mutual bite attempts and foot pushes (Diamond and Bond, 2002). They often sequentially reverse positions. Although keas roll over and jump on each other's stomachs, their play sequences commonly include actions taken while standing, including bite attempts, foot pushes, and bouts of mutual jump and flap. Fighting play also seems more aggressive in keas than in kakas, particularly with respect to their use of biting and wrestling with the bill. While kakas often gape at each other during play, we rarely observed them to bite their partners even during vigorous interactions. Kea play, in contrast, includes long bouts of bill locking, twisting and wrestling with each other using the bill, bouts that may persist even while one bird is standing on the stomach of the other. We repeatedly observed keas to bite each other during play, grabbing their partner by the tail, feet, or legs with their bills and even occasionally dragging the partner across the ground (Diamond and Bond, 1999).

Play fighting among wild parrots is most commonly observed among juveniles. In captivity, however, adult or subadult parrots often exhibit play fighting either between members of a mated pair or in interactions with human caretakers. A pair of captive red and green macaws (Ara chloropterus), for example, showed intense play fighting for 
up to $30 \mathrm{~min}$ at a time on the roof of the nest box, standing between branches or hanging head down (Deckert and Deckert, 1982). Captive kakapos (Strigops habroptilus) play fight by raising their wings at each other, waving their feet, and lunging at each other, in a manner similar to what we have observed in keas (Elliott, 2003, personal communication), and a captive hyacinth macaw (Anodorhynchus hyacinthinus) commonly sought out opportunities to wrestle playfully with zookeepers (Hick, 1962).

Compared to play fighting, play invitations occur among relatively few species. Both species of Nestor parrots show play invitations of a generally similar form. For example, both species display a head cock at the onset of a play interaction, both perform a distinctive, hopping approach to a prospective play partner, and both species roll over on their backs as a means of soliciting initiation or resumption of social play. Keas in captivity have been recorded as showing additional forms of play invitation behavior. Keller (1975) reported four different play invitations in captive keas: 1 ) a stiff legged walk with the head directed toward the partner; 2) non-directed throwing of objects; 3) lying on the back, frequently with the head between the legs; and 4) parrying or lifting a foot while ducking and touching. In our observations of wild kea, most play sessions were initiated with head-cocks, hopping approaches, or rolling over. Tossing in keas was only associated with play among mature birds of opposite sexes, inferred to be a form of courtship play (Diamond and Bond, 1999).

Aside from our observations of wild kea and kaka, play invitations have been noted only in captive or semi-captive parrots: kakapos, white-fronted parrots, red-and-green macaws, and hyacinth macaws. For example, Elliott and his associates observed hand-reared kakapos to roll on their backs, waving their feet in the air as a play invitation to human handlers (Elliott, 2003, personal communication), similar to play invitations in Nestor. Like kakas, captive hyacinth and red and green macaws solicit human play interaction by a hopping approach with the head obliquely inclined, followed by rolling over on their backs (Hick, 1962; Deckert and Deckert, 1982). White-fronted parrots solicit play by sidling up to the other bird with head and body lowered (Skeate, 1985).

One of the most striking differences between keas and other parrots that are known to play, including kakas, is in their use of objects. Among keas, object play is a common component of both individual and group activities (Diamond and Bond, 1991, 1999). Whereas kakas 
share many features of kea play, we never observed them to use objects in their social play (Diamond and Bond, 2002). A pair of fledgling keas, however, will often contest for a single object, such as a stick, a bone, or a piece of cloth, pulling at it from both ends or repeatedly stealing it away from one another. That such interactions are actually play, rather than simple competitive aggression, is suggested by the fact that object-oriented games often give way to active play fighting, leaving the contested object behind. A frequent type of object play in keas involves repeatedly tossing a small item in the air (Potts, 1969).We recorded keas tossing rocks, bottle caps, seed pods, walnuts and other small objects, especially during play interactions between individuals of opposite sexes, during which the tossing bird would also vocalize, jump and flap, and roll over (Diamond \& Bond, 1999). Solitary object play is pervasive, but it is also highly facilitative. One kea playing with an object will often attract several more, leading eventually to a group of young birds all excitedly tugging on the same item. We once observed a group of fledglings spend almost an hour pulling on a long piece of surgical gauze, walking around with it and periodically hopping, jumping, and foot pushing (Diamond \& Bond, 1999). With the exception of keas, social object play has not been unambiguously recorded in parrots. Although all parrots manipulate and demolish inedible items, they apparently do not commonly incorporate these objects into their social play interactions.

\section{Social play in other birds}

Other than parrots, social play has been recorded in only four families of birds: two families of hornbills, Eurasian babblers, and corvids. Among those species that engage in social play, there are more similarities than differences. Two species of hornbills have been recorded as showing play chases and/or play fighting (Table 1). Juvenile southern ground hornbills (Bucorvus leadbeateri) engage in fast aerial chases, bill wrestling, jumping on or over each other (Kemp, 2001). Young silverycheeked hornbills (Ceratogymna brevis) "barge" each other and wrestle with their bills (Moreau and Moreau, 1944). Kemp (2001) has also recorded social object play in ground hornbills, noting that juveniles "play tug-of-war with twigs."

Social play has also been observed in several species of Eurasian babblers. Jungle babblers (Turdoides striatus) perform mock fights in which some individuals lie on the ground, while others roll on top of 
them or gently peck them. This species also engages in play chases in which several juveniles fly rapidly and apparently aimlessly among the branches of a tree, twisting and turning in aerobatic maneuvers (Gaston, 1977). Similar play chases and mock fights were observed in large grey babblers (Turdoides malcolmi Hutson, 1954; Gaston, 1977). According to Zahavi (1990), play in Arabian babblers (Turdoides squamiceps) is similar to that of young mammals, including mock fighting and rolling on the ground. They play chase, trying to replace one another from particular locations, and "playtug" twigs with one another (Posis, 1984, cited in Zahavi, 1990).

The corvids are the only group of birds other than parrots in which social play appears to be broadly distributed (Fagen, 1981; Ortega and Bekoff, 1987). Ravens, in particular, have frequently been cited as exhibiting social play that is on a par with that of keas (Gwinner, 1966; Ficken, 1977; Fagen, 1981; Van Vuren, 1984; Ortega and Bekoff, 1987; Heinrich and Smolker, 1998). Raven social play primarily involves play chases and social object manipulation. Ravens play chase in flight, slide down inclines, and hang upside down, sometimes with one foot dangling, and play tug of war with sticks (Gwinner, 1966; Heinrich and Smolker, 1998). Ravens have been observed play fighting with mutual bill biting while grasping each other's claws (Eklow, 1988), but this may not occur in all raven populations. Heinrich and Smolker (1998) noted that "young ravens do not engage in the kind of obvious play fights that are so pervasive in young felids or canids" (p. 42). These authors similarly state that they did not observe play invitations in ravens. American crows (Corvus brachyrhyncos) and white-necked ravens (Corvus albicollis) engage in social object play, but have not been recorded as showing other forms of social play. Kilham (1989) recorded yearling crows as playing tug-of-war with Spanish moss. White-necked ravens have been observed playing "king of the castle," where a bird standing on a grass clump would pick up a piece of dry cow dung or a small stick. His opponent would then charge up to him and wrestle for the object. Once the challenger leapt at the other bird and struck with its feet. Another time, the bird with the twig appeared to throw it at his opponent (Moreau and Moreau, 1944).

The endemic Australian corvids, particularly apostlebirds (Struthidea cinerea, Baldwin, 1974), white-winged choughs (Corcorax malanorhamphos, Heinsohn, 2003, personal communication; Chisholm, 1958), and Australasian magpies (Pellis, 1981a, b, 1982), show a full range of play behaviors, including play chases, play fighting, play invitations, and social object play. Australasian magpies and apostle- 
birds may be the only avian species other than keas that show all four types of social play. Some behaviors used in these corvid interactions, particularly play invitations, show similarities to those of parrots. For example, apostlebirds invite play by rolling over on their backs, much as keas and kakas do. According to Baldwin (1974), a dominant male may voluntarily turn over, relax his claws, and let other birds peck his abdomen for a while, then jump clear and lead a chase around neighboring trees. White-winged choughs and apostlebirds also engage in social object play, primarily tug-of-war with sticks and leaves, sometimes while rolling over on their backs (Chisholm, 1958; Baldwin, 1974). Australasian magpies invite play by engaging in a "bouncy walk" that typically leads to play fighting. In this display both feet leave the ground together, the head and neck are retracted, and the torso is slightly lowered at the onset of each bounce (Pellis, 1981a). Sometimes short bouts of play fighting are interspersed within longer bouts of other interactions. Social object play is apparently less common in Australasian magpies than either play fighting or play chasing and typically involves one bird attempting to take away another's play object (for example, a twig or leaf).

The most conspicuous difference between social play in corvids and that of parrots is the degree to which it revolves around objects. Black-billed magpies show only play chasing, but all other corvids known to play socially do so wholly or partly in the context of object manipulation (Moreau and Moreau, 1944; Kilham, 1989; Deckert, 1991; Heinrich and Smolker, 1998). When compared across all available species records, using one observation per genus to reduce statistical dependencies (Harvey and Pagel, 1991), social object play was significantly more frequent in corvids than in parrots (Fisher's exact test, $p=0: 01$ ), suggesting that social play has evolved a distinctly different appearance in the two families and possibly serves different functions.

\section{Play, brain size, and development}

Ortega and Bekoff (1987) remarked that parrots and passerines, two groups of birds in which play has commonly been observed, also have relatively larger brains than other avian taxa. Whether brain size is statistically predictive of the occurrence of social play in birds is not evident from the literature, however. The occurrence of play has also been associated with altriciality, behavioral flexibility, and soci- 
ality (Ortega and Bekoff, 1987; Skutch, 1987), and these variables are to some degree intercorrelated with brain size (Bennett and Harvey, 1985a, b; Lefebvre et al., 2002, 2001, 1998, 1997; Sol and Lefebvre, 2000; Timmermans et al., 2000; Sol et al., 2002). To explore the relationship between social play, brain size, and ontogeny in individual species, we categorized the species of Psittacidae and Corvidae in Table 1 (the families for which we had the most extensive data) based on whether they showed only play chases or play fighting (here considered "simple" social play) or whether they additionally showed play invitations or social object play (categorized as "complex" social play). The resulting "play index" ( $1=$ simple; $2=$ complex $)$ is comparable to the methods used by Iwaniuk et al. (2001) to categorize play complexity in mammals.

The social play index was combined with additional data from the literature on brain size, body size, and age of first reproduction (Table 2). Body masses were generally obtained from Dunning (1993), after standardizing the taxonomy to that of Sibley and Ahlquist (1990) and Monroe and Sibley (1993), though values for several species had to be obtained from other sources (Fernandez et al., 1997; Woxvold, personal communication, 2003). Brain sizes were obtained from Mlikovsky (1989, 1990), integrated with more recent data (Rehkämper et al., 1991; Fernandez et al., 1997; Iwaniuk and Nelson, 2002). Brain masses were unavailable for several species known to play socially, but in four cases, we were able to substitute values from congeneric species of comparable body (Amazona leucocephala for A. albifrons; Chalcopsitta atra for C. sintillata; Psephotus haematonotus for P. chrysopterygius; and Forpus passerinus for $F$. conspicillatus). The only species for which brain sizes could not be approximated from published sources were the Australian Corcoracinae-Struthidea and Corcorax. Age of first reproduction was estimated from the literature for all but one of the species (citations in table). In general, birds showing more complex social play tend to be larger, to have absolutely larger brain sizes, and to take longer to reach sexual maturity. With only one exception, larger birds with longer development times show complex social play, while smaller, more rapidly developing birds show simple play.

To determine the influence of brain size and ontogeny on social play independent of body size, we extracted relative measures as residuals from allometric regressions (Jerison, 1973; Bennett and Harvey, 1985a; Gaillard et al., 1989; Timmermans et al., 2000; Iwaniuk et al., 2001). For the brain size measures, we log-transformed our tabled values and calculated residuals from Nealen and Ricklefs' (2001) major axis regres- 
Table 2. Play, morphometrics, and age of first reproduction in parrots and corvids

\begin{tabular}{|c|c|c|c|c|c|}
\hline Species & $\begin{array}{l}\text { Play } \\
\text { index }\end{array}$ & $\begin{array}{r}\text { Body } \\
\text { mass }(\mathrm{g})\end{array}$ & $\begin{array}{r}\text { Brain } \\
\text { mass }(\mathrm{g})\end{array}$ & $\begin{array}{r}\text { First rep } \\
(\mathrm{yr})\end{array}$ & $\begin{array}{l}\text { Reference to age } \\
\text { of first reproduction }\end{array}$ \\
\hline \multicolumn{6}{|l|}{ Psittacidae } \\
\hline Chalcopsitta sintillata & 1 & 195 & 5.90 & $1-2$ & $\begin{array}{l}\text { Low, 1977; } \\
\text { Higgins, } 1999\end{array}$ \\
\hline Pseudeos fuscata & 1 & 149 & 4.20 & $1-2$ & $\begin{array}{l}\text { Low, 1977; } \\
\text { Higgins, } 1999\end{array}$ \\
\hline Elophus roseicapillus & 1 & 337 & 6.78 & $2-3$ & Rowley, 1990 \\
\hline Nestor notabilis & 2 & 868 & 15.50 & $3-4$ & Jackson, 1963a \\
\hline Nestor meridionalis & 2 & 455 & 9.50 & $2-3$ & Holland, 1999 \\
\hline Psephotus chrysopterygius & 1 & 70 & 2.00 & 1 & Forshaw, 1977 \\
\hline Melopsittacus undulatus & 1 & 29 & 1.37 & $\leq 1$ & Forshaw, 1977 \\
\hline Strigops habroptilus & 2 & 1670 & 14.50 & 9 & Elliott et al., 2001 \\
\hline Anodorhynchus hyacinthinus & 2 & 1500 & 24.50 & $4-7$ & $\begin{array}{l}\text { Lücker and Patzwahl, } \\
2000\end{array}$ \\
\hline Ara chloroptera & 2 & 1400 & 23.40 & $5-7$ & Munn, 1992 \\
\hline Myiopsitta monachus & 1 & 92 & 3.83 & 2 & $\begin{array}{l}\text { Martín and Bucher, } \\
1993\end{array}$ \\
\hline Forpus conspicillatus & 1 & 25 & 1.20 & 1 & Forshaw, 1977 \\
\hline Amazona albifrons & 2 & 233 & 6.40 & 3-5 & Levinson, 1980 \\
\hline \multicolumn{6}{|l|}{ Corvidae } \\
\hline Corcorax melanorhamphos & 2 & 364 & - & 4 & Rowley, 1978 \\
\hline Struthidea cinerea & 2 & 131 & - & 3-4 & Chapman, 1998 \\
\hline Pica pica & 1 & 183 & 5.76 & $1-2$ & Birkhead, 1991 \\
\hline Corous brachyrhynchos & 2 & 421 & 8.00 & $3-5$ & McGowen, 1996 \\
\hline Corous corax & 2 & 1144 & 15.26 & 3-4 & Ratcliffe, 1997 \\
\hline Corvus albicollis & 2 & 900 & 12.00 & - & \\
\hline Gymnorhina tibicen & 2 & 330 & 4.98 & $3-4$ & Veltman, 1989 \\
\hline
\end{tabular}

sion of avian brain and body masses. To correct the age of first reproduction for body size effects, we combined the values in Table 2 with the broader survey provided in Appendix 2 of Gaillard et al. (1989) and conducted a major axis regression on the log-transformed data (Sokal and Rohlf, 1981; Seim and Saether, 1983). Body size and age of first reproduction were significantly associated, with the allometric regression accounting for $93 \%$ of the variance (mean log body mass $=5.94$; mean log age of maturity $=0.62$; slope $=0.255$ ).

Residual measures of brain size and age of first reproduction were then analyzed for effects of play complexity (Figure 1). To reduce 

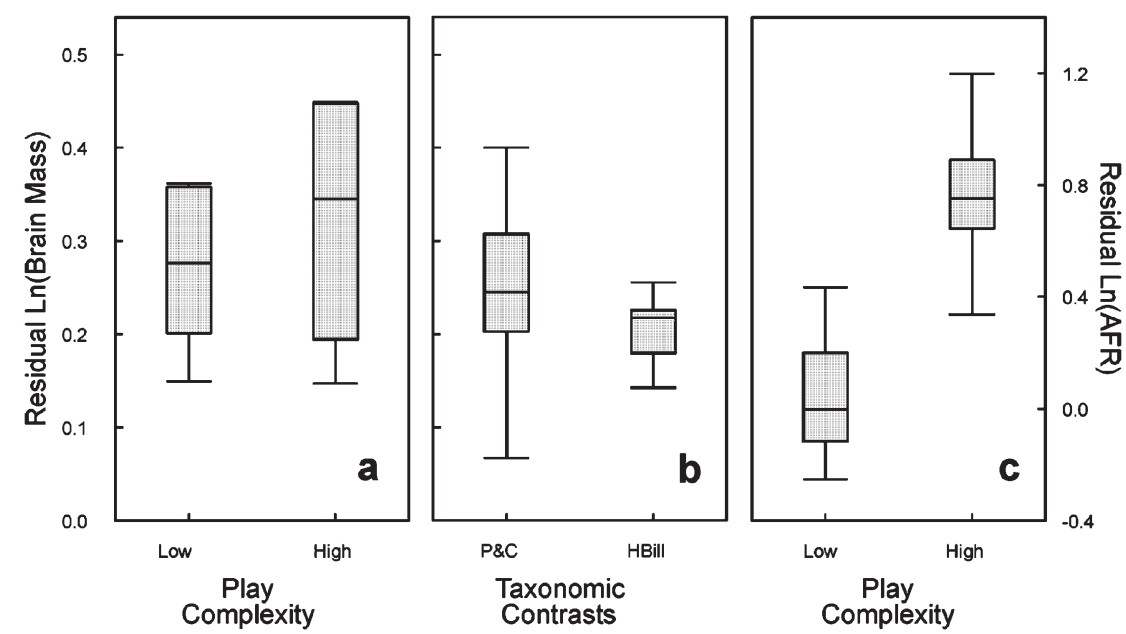

Figure 1. Contrasts in brain size and age of first reproduction (AFR). Data from individual species were log-transformed and corrected for body size effects by converting to residuals of major axis allometric regressions. Box plots display medians, hinges, and adjacent values from the distribution of residuals averaged within genera. a: Average residual log brain sizes for Low $(N=8$ genera) and High ( $N=7$ genera) play complexity groups of parrots and corvids. $\mathbf{b}$ : Comparison taxa $-\mathrm{P} \& C(N=32$ genera $)$ are genera of parrots and corvids not described as showing social play; HBill ( $N=6$ genera) are genera of hornbills, two of which were described as showing social play. c: Residual log age of first reproduction for Low $(N=8)$ and High $(N=7)$ play complexity groups of parrots and corvids.

statistical dependency, average residuals were calculated for Corvus and Nestor, both of which were represented by two or more species, and analyses were conducted at the generic level (Harvey and Pagel, 1991). More precise methods for controlling for phylogenetic relationships are available (Iwaniuk et al., 2001), but they could not feasibly be employed in this case, given the small sample size and the uncertain state of knowledge of parrot systematics (Sibley and Ahlquist, 1990). Residual brain sizes (Figure 1a) were significantly greater than zero for species with both simple and complex social play (simple: $t(7)=$ 9.26, $p<0.001$; complex: $t(6)=7.23, p<0$ :001), but the two groups did not differ significantly from each other (Wilcoxon rank sums, $W^{+}(8$, $7)=64, p>0.4$ ). Parrots and corvids are generally considered to have relatively larger brains than other, unrelated birds with similar body sizes (Ortega and Bekoff, 1987), which could account for the significantly positive residuals. The alternative hypothesis, however, is that 
parrots and corvids that show any level of social play have relatively larger brains, that social play per se is associated with larger brain size (as is true, at least at the ordinal level, in mammals: Iwaniuk et al., 2001).

To test this hypothesis, we constructed a comparison group, consisting of all parrots and corvids in Mlikovsky's $(1989,1990)$ data base that were not included in our survey of social play. Brain size and body size for this set of 66 species were log-transformed, and residual brain sizes were calculated from Nealen and Ricklefs' (2001) allometric regression (Figure 1b). For analysis, the species residuals were averaged within genera, as discussed above, and genera that were included in the social play data were removed. As expected, residual brain sizes in this comparison group were also significantly greater than zero $(t(31)=16.2, p$ $<0: 001)$. Brain sizes for species with both simple and complex social play did not differ significantly from those in the comparison group, however (simple: $W^{+}(8,32)=186, p>0.4$; complex: $W^{+}(7,32)=180, p$ $>0: 15)$. Parrots and corvids that play socially at any level of complexity do not appear to have larger relative brain sizes than are characteristic of the families as a whole. It should be noted that there are undoubtedly a number of species in our comparison group that do play socially, but that have not been observed to do so. As a result, this analysis may be unduly conservative.

Relative brain size is, however, greater in these two playful avian families than would be expected from the allometric regression of brain and body size for birds as a whole, much as Ortega and Bekoff (1987) assumed. To test whether this relationship might hold for other avian taxa from which extensive social play had been recorded, we conducted the same analysis of residual brain size averaged within genera for the Bucerotiformes. The six genera of hornbills in Mlikovsky's (1989; corrected to accord with Sibley and Monroe, 1990) data base (including two that had been recorded as showing play fighting or social object play) showed significantly higher relative brain sizes than expected (Figure $1 b ; t(5)=15.1, p<0: 001$ ), supporting the notion that extensive social play in birds may generally be associated with relatively large brain sizes. Because the complexity of social play was not significantly associated with brain size when comparing among genera of parrots and corvids, however, we must infer that the relationship between brain size and play differs according to the rank of the taxon being analyzed (Harvey and Pagel, 1991; but see Byers, 1999), as Iwaniuk et al. (2001) discovered in a similar species-based analysis of play in mammals. 
A similar, generic-level analysis of the relationship between social play complexity and age of first reproduction, in contrast, showed a statistically significant difference $\left(W^{+}(8,9)=37, p<0: 001\right)$, with the complex social play species taking considerably longer to reach maturity (Figure 1c). The residual age of first reproduction for the complex play group was also significantly greater than zero $(t(8)=9.19, p<$ $0.001)$, while that for the simple play group was not $(t(7)=0.52, p>0.6)$. Parrots and corvids that exhibited simple social play thus showed an age of maturity that was entirely in line with what would be expected of an average bird of their body size, while those that exhibited more complex social play showed a greater age of first reproduction than expected. This suggests that complex social play may be functionally distinctive from simple social play and that it may have evolved in association with a later age of first reproduction. Our findings are consistent with analyses of play in mammals that have demonstrated a strong association between play complexity and the length of the juvenile phase, even when the data are corrected for body size effects (Joffe, 1997; Pellis and Iwaniuk, 2000).

\section{Discussion}

The phylogenetic distribution of social play in birds suggests that fully realized play fighting, play invitation, or social object play has evolved separately in at least four different lineages, including parrots, corvids, hornbills, and Eurasian babblers. Of these, only parrots and corvids currently provide a sufficient sample of playing species to allow for tentative interpretations of the pattern of evolution of the behavior. Social play appears to be widely distributed among the Psittacidae, occurring in at least some form even in species as ecologically and taxonomically distant as budgerigars and hyacinthine macaws. In addition, many of the characteristic action patterns of Nestor social play, including rolling over, hopping, bill fencing, and wing flapping, are displayed in similar forms and contexts across some species in both the Australasian and the South American radiations (Smith, 1975; Sibley and Ahlquist, 1990; Christidis et al., 1991). It is possible that social play behaviors may be phylogenetically primitive in the Psittacidae, and that parrot species that have not been recorded as showing social play either may have lost the behavior secondarily or may not yet have been observed under appropriate environmental or developmental circumstances. 
The phylogeny of social play in corvids appears to have taken a different course. The form of the behavior is readily distinguishable from that in parrots. Social object play is significantly more frequent in corvids and, with the exception of the cooperatively breeding Australian species, play invitations appear to be less common. This suggests that the selective factors that led to social play in corvids may have differed from those in parrots. Corvids show more foraging innovation than parrots and more tool use (Lefebvre et al., 1998, 2001, 2002), suggesting that exploratory or playful object manipulation is a more common feature of corvid behavior, and its incorporation into their social play may have parallels to the evolution of social object play in keas.

Our analyses of the effects of relative brain size and age of first reproduction suggest that social play in birds has evolved in response to a range of causal factors operating at different taxonomic levels. Higher-level taxa that include socially playing species (corvids, parrots, and hornbills) have significantly larger relative brain sizes than would be expected of an average bird of similar body size, confirming the suggestions of previous authors (Fagen, 1981; Ortega and Bekoff, 1987). Brain size is only one component of a larger adaptive complex, however. These avian groups are also characterized by altricial development, and altriciality has also been found to be associated with both higher incidence of play behavior (Ortega and Bekoff, 1987) and larger relative brain size (Bennett and Harvey, 1985b).

The fact that we found brain size to have no predictive value with respect to the complexity of social play within taxa, however, suggests that its causal associations with social play are rather remote (Iwaniuk et al., 2001). At the ordinal or family level, differences in relative brain size are probably best viewed as part of a large-scale life history variation in birds. In more altricial species, greater post-hatching parental investment is associated with smaller clutch sizes and larger adult brains (Bennett and Harvey, 1985a, b; Ricklefs and Starck, 1998). Large relative brain size and altricial development may, thus, be considered preconditions for the evolution of play behavior, rather than direct causal factors (Table 3; Harvey and Pagel, 1991).

Within these altricial taxa, the evolution of social play appears to be promoted in families or genera that show higher levels of sociality, of associations or relationships between multiple individuals that persist over time (Table 3). Skutch (1987) provides a number of examples of social play in cooperatively breeding species, including Australian corvids, ground hornbills, and babblers, all of which were cited in our lit- 
Table 3. The occurrence and complexity of social play in birds is influenced by different causal factors at different taxonomic levels

\begin{tabular}{lll}
\hline Taxonomic level & Life history variable or factor & Occurrence/ Type of play \\
\hline Order/Family & Larger brain size/Altriciality & Enables evolution of play \\
Family/Genus & Sociality/Cooperative breeding & Promotes social play \\
Genus/Species & $\begin{array}{l}\text { Delayed reproduction/Persistent } \\
\text { association of juveniles with adults }\end{array}$ & $\begin{array}{l}\text { Selects for complex social play } \\
\text { in taxa in which social play is } \\
\text { relatively common }\end{array}$ \\
\hline
\end{tabular}

erature survey (Table 3). Parrots do not breed cooperatively, but many of them are highly gregarious, particularly outside of the breeding season, with fledged young forming persisting associations with parents or other juvenile birds (Rowley, 1990; Munn, 1992; Collar, 1997; Juniper and Parr, 1998; Diamond and Bond, 1999). Similar social attachments are exhibited in many of the larger corvids, as well (Kilham, 1989; Ratcliffe, 1997). Sociality does not compel the evolution of social play, however, even in taxa that are well-represented with playful species. Cooperatively breeding corvids in North America have been studied intensively for many years (e.g. Woolfenden and Fitzpatrick, 1984, 1990; Brown, 1987; Skutch, 1987; Marzluff and Balda, 1992). These studies have yielded some suggestions of solitary play (Skutch, 1987; Marzluff and Balda, 1992), but no unambiguous instances of social play have been noted.

Within avian taxa that show social play, the behavior appears to acquire a more complex, differentiated form in species in which delayed reproduction is accompanied by persistent associations between juveniles and adults (Table 3). Delayed maturation alone is not sufficient, as there are numerous avian taxa in which young birds require years of experience prior to beginning breeding, but from which no instances of social play have ever been documented (e.g. Pelecanidae, Ciconiidae, or Procellariidae; Gaillard et al., 1989). The addition of a persisting association between conspecifics and post-fledging juveniles appears to be crucial in promoting complex social play. For example, juvenile keas and kakas engage in complex social play when they aggregate with adults at feeding sites. Complex social play in apostlebirds occurs between juvenile helpers within a cooperatively breeding family group. In Arabian babblers, complex social play is observed among juvenile birds remaining in their parental group over a subsequent breeding season. The factors that facilitate the occurrence of simple social play - play chasing 
and play fighting - are less evident, but the fact that only complex social play shows an association with age of first reproduction suggests that these two behavioral categories may be functionally and evolutionarily distinct.

The association between delayed reproduction and complex play could simply reflect the consequences of a release from the evolutionary constraints that apply to young animals trying to make their own way in the world. Social play is potentially hazardous and, of necessity, it is generally accorded lower priority than predator avoidance, foraging, or intraspecific aggression (Fagen, 1981; Power, 2000). However, the combination of a prolonged nonreproductive phase with at least adventitious custodial care by adults may provide the necessary protective environment that would allow selection for social play to operate (Diamond and Bond, 1999). In this view, juvenile birds that exhibit complex play may be experiencing a social environment that is similar, in many ways, to that of juvenile mammals. Social play in the most playful species of birds certainly rivals that of carnivores and possibly that of primates (Fagen, 1981; Ortega and Bekoff, 1987). Yet play is broadly distributed among mammals and, in contrast, relatively limited among birds (Iwaniuk et al., 2001). There are undoubtedly many reasons for this striking difference between the vertebrate classes, but it is worth noting that long, protected juvenile phases with extended parental care are characteristic of mammalian social development and generally rare among birds (Ewer, 1973; Pagel and Harvey, 1993). If social play occurs primarily where there are persisting custodial associations between juveniles and adults, the conditions necessary for its evolution may be met with more often among mammals than among birds.

\section{References}

Ashmole, N. P. and Tovar, H. S. (1968). Prolonged parental care in royal terns and other birds. Auk 85, pp. 90-100.

Baldwin, M. (1974). Studies of the apostle bird at Inverell. Part 1. General behaviour. Sunbird 5, pp. 77-88.

Barber, N. (1991). Play and energy regulation in mammals. Q. Rev. Biol. 66, pp. 129-147.

Beach, F. A. (1945). Current concepts of play in animals. Am. Nat. 79, pp. 523-541.

Bekoff, M. (1974). Social play and play-soliciting by infant canids. Am. Zool. 14, pp. 323- 340.

Bekoff, M. (1976). Animal play: problems and perspectives. In: Perspectives in ethology, Vol. 2 (P. P. G. Bateson and P. H. Kolpfer, eds.). Plenum Pub. Company, New York, pp. 165-188. 
Bekoff, M. (1984). Social play behavior. Bioscience 34, pp. 228-233.

Bekoff, M. (1995). Play signals as punctuation. The structure of social play in canids. Behaviour 132, pp. 419-29.

Bekoff, M. and Allen, C. (1998). Intentional communication and social play: how and why animals negotiate and agree to play. In: Animal play: evolutionary, comparative and ecological perspectives (M. Bekoff and J. A. Byers, eds.). Cambridge University Press, Cambridge, pp. 97-114.

Bekoff, M. and Byers, J. A. (1981). A critical reanalysis of the ontogeny and phylogeny of mammalian social and locomotor play: an ethological hornet's nest. In: Behavioral development: The Bielefield interdisciplinary conference (K. Immelmann, G. Barlow, L. Petrinovich \& M. Main, eds.). Cambridge University Press, New York, pp. 296-337.

Bekoff, M. and Byers, J. A. (eds.. ) (1998). Animal play: evolutionary, comparative and ecological perspectives. Cambridge University Press, Cambridge.

Bekoff, M., Diamond, J. and Mitton, J. B. (1981). Life history patterns and sociality in canids: Body size, reproduction, and behavior. Oecologia 50, pp. 386-390.

Bennett, P. M. and Harvey, P. H. (1985a). Relative brain size and ecology in birds. J. Zool. (Lond. ) (A) 207, pp. 151-169.

Bennett, P. M. and Harvey, P. H. (1985b). Brain size, development and metabolism in birds and mammals. J. Zool. (Lond. ) (A) 207, pp. 491-509.

Birkhead, T. R. (1991). The magpies, the ecology and behavior of black-billed and yellow-billed magpies. T. and A. D. Poyser, London.

Blumstein, D. T. (1990). An observation of play in bearded vultures. Condor, 92, pp. 779- 781.

Bond, A. B. and Kamil, A. C. (2002). Visual predators select for crypticity and polymorphism in virtual prey. Nature 415, pp. 609-613.

Bond, A. B., Kamil, A. C., and Balda, R. P. (2003). Social complexity and transitive inference in corvids. Anim. Behav. 65, pp. 479-487.

Brereton, J. L. G. (1971). Inter-animal control of space. In: Behavior and environment (A. H. Esser, ed. ). Plenum, New York, pp. 69-91.

Brown, J. L. (1987). Helping and communal breeding in birds: ecology and evolution. Princeton University Press, Princeton, NJ.

Burghardt, G. M. (1998). The evolutionary origins of play revisited: lessons from turtles. In: Animal play: evolutionary, comparative and ecological perspectives (M. Bekoff and J. A. Byers, eds.). Cambridge University Press, Cambridge, pp. 1-26.

Burghardt, G. M. (2001). Play attributes and neural substrates. In: Handbook of behavioral neurobiology, Vol. 13 (E. Bass, ed. ). Kluwer Academic/Plenum Publishers, New York, pp. 317- 356.

Byers, J. A. (1999). The distribution of play behavior among Australian marsupials. J. Zool. (Lond. ) 247, pp. 349-356.

Chapman, G. (1998). The social life of the apostlebird, Struthidea cinerea. Emu 98, pp. 178- 183.

Chisholm, A. H. (1958). Bird wonders of Australia. Holt Rinehart and Winston, New York.

Christidis, L., Schodde, R., Shaw, D. D., and Maynes, S. F. (1991). Relationships among the Australo-papuan parrots, lorikeets, and cockatoos (Aves: Psittaci- 
formes): Protein evidence. Condor 93, pp. 302-317.

Collar, N. J. (1997). Family psittacidae (parrots). In: Handbook of birds of the world, Vol. 4: Sandgrouse to cuckoos (J. del Hoyo, A. Elliott and J. Sargatal, eds.). Lynx Edicions, Barcelona, pp. 280-477.

Deckert, G. (1991). Spielverhalten bei Elstern, Pica pica (L. ), und Grünflügelaras, Ara chloroptera G. R. Gray. Mitt. Zool. Mus. Berl. 67 Suppl. : Ann. Orn. 15, pp. 55-64.

Deckert, G. and Deckert, K. (1982). Spielverhalten und Komfortbewegungen beim Grünflügelara (Ara chloroptera G. R. Gray). Bonn. Zool. Beitr. 33(2-4), pp. 269-281.

Diamond, J. and Bond, A. B. (1991). Social behavior and the ontogeny of foraging in the kea (Nestor notabilis). Ethology 88, pp. 128-144.

Diamond, J. and Bond, A. B. (1999). Kea, bird of paradox, the evolution and behavior of a New Zealand parrot. University of California Press, Berkeley, CA.

Diamond, J. and Bond, A. B. (2002). Play in parrots. Interpretive Birding 3, pp. 56-57.

Dunning, J. B, Jr. (ed. ). (1993). CRC handbook of avian body masses. CRC Press, Boca Raton, FL.

Eklow, A. (1988). The behaviour of ravens Corvus corax, in fresh snow. Var-Fagelvarld 47, pp. 89-90.

Elliot, G. P., Merton, D. V. and Jansen, P. W. (2001). Intensive management of a critically endangered species: the kakapo. Biol. Conserv. 99, pp. 121-133.

Engesser, U. (1977). Sozialisation junger Wellensittiche (Melopsittacus undulatus). Z. Tierpsychol. 43, pp. 68-105.

Ewer, R. F. (1973). The carnivores. Comstock Pub. Co., Ithaca, NY.

Fagen, R. (1981). Animal play behavior. Oxford University Press, New York.

Felsenstein, J. (1985). Phylogenies and the comparative method. Am. Nat. 125, pp. 1-15.

Fernandez, P., Carezzano, F. and Speroni, N. B. de (1997). Análisis cuantitativo encefálico e índices cerebrales en Aratinga acuticaudatay Myiopsittamonachus de Argentina (Aves: Psittacidae). Rev. Chil. Hist. Nat. 70, pp. 269-275.

Ficken, M. S. (1977). Avian play. Auk. 94, pp. 573-582.

Forshaw, J. M. (1977). Parrots of the world. T. F. H. Publications, Neptune, NJ.

Fossey, D. (1978). Development of the mountain gorilla (Gorilla gorilla beringei): The first thirty-six months. In: The great apes (D. Hamburg and E. McCowen, eds.). Benjamin/Cummings, Menlo Park, CA, pp. 139-185.

Gaillard, J. M., Pontier, D., Allainé, D., Lebreton, J. D., Trouvilliez, J. and Clobert, J. (1989). An analysis of demographic tactics in birds and mammals. Oikos 56, pp. 59-76.

Gamble, J. R. and Cristol, D. A. (2002). Drop-catch behavior is play in herring gulls, Larus argentatus. Anim. Behav. 63, pp. 339-345.

Garnetzke-Stollmann, K. and Franck, D. (1991). Socialization tactics of the spectacled parrotlett (Forpus conspicillatus). Behaviour 119, pp. 1-29.

Garvey, C. (1990). Play. Harvard University Press, Cambridge, MA.

Gaston A. J. (1977). Social behavior within groups of jungle babblers (Turdoides striatus). Anim. Behav. 25, pp. 828-848.

Groos, K. (1898). The play of animals. D. Appleton and Co., New York, NY. 
Gwinner, E. (1966). Über einige Bewegungspiele des Kohlraben (Corvus corax L. ). Z. Tierpsychol. 23, pp. 28-36.

Harvey, N. C., Farabaugh, S. M. and Druker, B. B. (2002). Effects of early rearing experience on adult behavior and nesting in captive Hawaiian crows. Zoo Biol. 21, pp. 59-75.

Harvey, P. H. and Pagel, M. D. (1991). The comparative method in evolutionary biology. Oxford U. Press, Oxford.

Heinrich, B. and Smolker, R. (1998). Play in common ravens (Corvus corax). In: Animal play: Evolutionary, comparative and ecological perspectives (M. Bekoff and J. A. Byers, eds.). Cambridge University Press, Cambridge, pp. 27-44.

Hick, U. (1962). Beobachtungen über das Spielverhalten unseres Hyazinth Ara (Anodorhynchus hyacinthus). Freunde d. Kölner Zoo 5, pp. 8-9.

Higgins, P. J. (editor 1999). Handbook of Australian, New Zealand and Antarctic birds. Vol. 4. Parrots to dollarbird. Oxford University Press, Victoria.

Holland, G. (1999). Kaka breeding at Mt Bruce. OSNZ Supplement, Notornis 46, pp. 1.

Hutson, H. P. W. (1954). The birds about Dehli. Delhi Birding Watching Society, Dehli.

Iwaniuk, A. N. and Nelson, J. E. (2002). Can endocranial volume be used as an estimate of brain size in birds? Can. J. Zool. 80, pp. 16-23.

Iwaniuk, A. N., Nelson, J. E., and Pellis, S. M. (2001). Do big-brained animals play more? Comparative analysis of play and relative brain size in mammals. J. Comp. Psych. 115, pp. 29-41.

Jackson, J. R. (1963a). The nesting of keas. Notornis 10, pp. 319-26.

Jackson, J. R. (1963b). Studies at a kaka's nest. Notornis 10, pp. 168-176. Jerison, H. J. (1973). Evolution of the brain and intelligence. Academic Press, New York, NY.

Joffe, T. H. (1997). Social pressures have selected for an extended juvenile period in primates. J. Hum. Evol. 32, pp. 593-605.

Juniper, T. and Parr, M. (1998). Parrots: A guide to parrots of the world. Yale University Press, New Haven, CT.

Keller, R. (1975). Das Spielverhalten der Keas (Nestor notabilis Gould) des Zürcher Zoos. Z. Tierpsychol. 38, pp. 393-408.

Kemp, A. C. (2001). Family Bucerotidae (Hornbills). In: Handbook of birds of the world, Vol. 6, Mousebirds to Hornbills (J. del Hoyo, A. Elliott and J. Sargatal, J., eds.). Lynx Edicions, Barcelona, pp. 436-523.

Kemp, A. C. and Kemp, M. I. (1980). The biology of the southern ground hornbills Bucorvus leadbeateri (Vigors) (Aves: Bucerotidae). Ann. Transvaal Mus. 32, pp. 65-100.

Kilham, L. (1974). Play in hairy, downy and other woodpeckers. Wilson Bull 86, 35-42.

Kilham, L. (1984). Play-like behavior of American crows. Florida Field Naturalist 12, pp. 33-36.

Kilham, L. (1989). The American crow and the common raven. Texas University Press, College Station, TX.

Lefebvre, L., Gaxiola, A., Dawson, S., Timmermans, S., Rosza, L. and Kabai, P. (1998). Feeding innovations and forebrain size in Australasian birds. Behaviour 135, pp. 1077- 1097. 
Lefebvre, L., Juretic, N., Nicolakakis, N., and Timmermans, S. (2001). Is the link between forebrain size and feeding innovations caused by confounding variables? A study of Australian and North American birds. Anim. Cogn. 4, pp. 91-97.

Lefebvre, L., Nicolakakis, N., and Boire, D. (2002). Tools and brains in birds. Behaviour 139, pp. 39-973.

Lefebvre, L., Whittle, P., Lascaris, E., and Finklestein, A. (1997). Feeding innovations and forebrain size in birds. Anim. Behav. 53, pp. 549-560.

Levinson, S. L. (1980). The social behavior of the white fronted amazon (Amazona albifrons). Int. Council for Bird Preservation Technical Pub. 1, pp. 403-417.

Lorenz, K. Z. (1956). Plays and vacuum activities. L'Instinct dans le Comportment des Animax et de L'Homme (ed. Autuori et al. ). Paris Fondation Singer-Polignac, Masson et Cie.

Low, R. (1977). Lories and lorikeets, The brush-tongued parrots. Paul Elek, London.

Lücker, H. and Patzwahl, S. (2000). The European endangered species programme (EEP) for the Hyacinth macaw Anodorhynchus hyacinthinus from 1989 to 1998. Int. Zoo Yb. 37, pp. 178-183.

Martín, L. F. and Bucher, E. H. (1993). Natal dispersal and first breeding age in Monk parakeets. Auk 110, pp. 930-933.

Marzluff, J. M. and R. P. Balda (1992). The pinyon jay: Behavioral ecology of a cooperative corvid. T and A D Poyser, London.

McGowen, K. J. (1996). Family lives of the uncommon American crow. Cornell Plantations Mag. 51, pp. 1-4.

Mech, L. D. (1970). The wolf, the ecology and behavior of an endangered species. University of Minnesota Press, Minneapolis, MN.

Mlikovsky, J. (1989). Brain size in birds: 3. Columbiformes through Piciformes. Vest Cs Spolec Zool. 53, pp. 252-264.

Mlikovsky, J. (1990). Brain size in birds: 4. Passeriformes. Acta Soc. Zool. Bohemoslov 54, pp. 27- 37.

Monroe, B. L. and Sibley, C. G. (1993). A world checklist of birds. Yale University Press, New Haven, CT.

Moreau, R. E. (1938). A contribution to the biology of the Musophagiformes, the so-called plantain eaters. Ibis 2, pp. 639-671.

Moreau, R. E. and Moreau, W. M. (1944). Do young birds play? Ibis 86, pp. 93-94.

Müller-Schwarze, D. (1978). Play behavior in the adelie penguin. In: Evolution of play behavior (D. Müller-Schwarze, ed. ). Dowden, Hutchinson and Ross, Inc., Stroudsburg, Pennsylvania, pp. 375-377.

Munn, C. A. (1992). Macaw biology and ecotourism, or "when a bird in the bush is worth two in the hand". In: New world parrots in crisis (S. R. Beissinger and N. F. R. Snyder, eds.). Smithsonian Institution Press, Washington, pp. 47-72.

Negro, J. J., Bustamante, J., Milward, J., and Bird, D. M. (1996). Captive fledgling American kestrels prefer to play with objects resembling natural prey. Anim. Behav. 52, pp. 707-714.

Nealen, P. M. and Ricklefs, R. E. (2001). Early diversification of the avian brain: body relationship. J. Zool. (Lond. ) 253, pp. 391-404.

Ortega, J. C. and Bekoff, M. (1987). Avian play: comparative evolutionary and developmental trends. Auk 104, pp. 338-341. 
Pagel, M. D. and Harvey, P. H. (1993). Evolution of the juvenile period in mammals. In: Juvenile primates: Life history, development, and behavior (M. E. Periera and L. A. Fairbanks, eds.). Oxford University Press, Oxford, pp. 28-37.

Pandolfi, M. (1996). Play activity in young Montagu's harriers (Circus pygargus). Auk 113, pp. 935-938.

Parker, S. T. and Milbrath, C. (1994). Contributions of imitation and role-playing games to the construction of self in primates. In: Self-awareness in animals and humans (S. T. Parker, R. Mitchell, and M. L. Boca, eds.). Cambridge U. Press, Cambridge, pp. 108-128.

Pellis, S. M. (1981a). Description of social play by the Australian magpie Gymnorhina tibicen Based on Eshkol-Wachman Notation. Bird Behav. 3, pp. 61-79.

Pellis, S. M. (1981b). Exploration and play in the behavioural development of the Australian magpie Gymnorhina tibicen. Bird Behav. 3, pp. 37-49.

Pellis, S. M. (1982). Development of head and foot coordination in the Australian magpie Gymnorhina tibicen, and the function of play. Bird Behav. 4, pp. 57-62.

Pellis, S. M. and Iwaniuk, A. N. (2000). Comparative analysis of the roles of postnatal development in the expression of play fighting in juveniles and adults. Dev. Psychobiol. 36, pp. 136- 147.

Pellis, S. M. and Pellis, V. C. (1996). On knowing it's only play: The role of play signals in play fighting. Agress. Violent Beh. 1, pp. 249-268.

Posis, O. (1984). Play in babblers. M. Sc. thesis. Tel-Aviv U. Israel (cited in Zahavi, 1990).

Potts, K. J. (1969). Ethological studies of the kea (Nestor notabilis) in captivity: Nonreproductive behavior. B. S. thesis. Victoria University, Wellington, New Zealand.

Power, T. G. (2000). Play and exploration in children and animals. Lawrence Erlbaum Assoc. Pubs. Mahwah, NJ.

Ratcliffe, D. (1997). The raven, a natural history in Britain and Ireland. T. and A. D. Poyser, London.

Rehkämper, G., Frahm, H. D., and Zilles, K. (1991). Quantitative development of brain and brain structures in birds (Galliformes and Passeriformes) compared to that in mammals (Insectivores and Primates). Brain Behav. Evolut. 37, pp. 125-143.

Ricklefs, R. E. and Starck, J. M. (1998). Evolution of developmental modes in birds. In: Avian growth and development: evolution within the altricial-precocial spectrum (J. M. Starck and R. E. Ricklefs, eds.). Oxford University Press, Oxford, pp. 31-58.

Rowley, I. (1978). Communal activities among white-winged choughs Corcorax malanorhamphos. Ibis 120, pp. 178-197.

Rowley, I. (1990). Behavioural ecology of the galah, Eolophus roseicapillus in the wheatbelt of Western Australia. Surrey Beatty and Sons Pty Limited, Chipping Norton, NSW.

Rowley, I. (1997). Family Cacatuidae (Cockatoos). In: Handbook of birds of the world, Vol. 4: Sandgrouse to cuckoos (J. del Hoyo, A. Elliott, and J. Sargatal, J., eds.). Lynx Edicions, Barcelona, pp. 246-279. 
Sauer, R. (1956). On the behavior of young garden warblers, Sylvia borin (Bodd), ontogeny and play. Reprinted in: Evolution of play behavior (D. MüllerSchwarze, ed.), 1978. Dowden, Hutchinson and Ross, Inc., Stroudsburg, PA, pp. 372-374.

Seim, E. and Saether, B. (1983). On rethinking allometry: Which regression model to use? J. Theor. Biol. 104, pp. 161-168.

Shepherd, P. (1968). Some notes on the breeding of the Quaker parakeet (Myiolsitta monarchus). Avicult. Mag. 74, pp. 210-211.

Sibley, C. G. and Ahlquist, J. E. (1990). Phylogeny and classification of birds. Yale University Press, New Haven, CT.

Simmons, R. E. and Mendelsohn, J. M. (1993). A critical review of cartwheeling flights of raptors. Ostrich 64, pp. 13-24.

Skeate, S. T. (1985). Social play behaviour in captive white-fronted Amazon parrots Amazona albifrons. Bird Behav. 6, pp. 46-48.

Skutch, A. F. (1987). Helpers at birds' nests. University of Iowa Press, Iowa City, IA.

Smith, G. A. (1975). The systematics of parrots. Ibis 117, pp. 18-68.

Smith, S. M. (1977). The behavior and vocalizations of young turquoise-browed motmots. Biotropica 9, pp. 127-130.

Sokal, R. R. and Rohlf, F. J. (1981). Biometry. W. H. Freeman and Company, New York, NY.

Sol, D. and Lefebvre, L. (2000). Behavioral flexibility predicts invasion success in birds introduced to New Zealand. Oikos 90, pp. 599-605.

Sol, D. , Timmermans, S., and Lefebvre, L. (2002). Behavioral flexibility and invasion success in birds. Anim. Behav. 63, pp. 495-502.

Spinka, M., Newberry, R. C. and Bekoff, M. (2001). Mammalian play: training for the unexpected. Quart. Rev. Biol. 76, pp. 141-168.

Stonehouse, B. and Stonehouse, S. (1963). The frigate bird Fregata aethiops of Ascension Island. Ibis 103b, pp. 409-422.

Timmermans, S., Lefebvre, L., Boire, D., and Basu, P. (2000). Relative size of the hyperstriatum ventrale is the best predictor of feeding innovation rate in birds. Brain Behav. Evol. 56, pp. 196-203.

Van Vuren, D. (1984). Aerobatic rolls by ravens on Santa Cruz Island, California. Auk 101, pp. 620-621.

Veltman, C. J. (1989). Flock, pair and group living lifestyles without cooperative breeding by Australian magpies Gymnorhina tibicen. Ibis 131, pp. 601-608.

Woolfenden, G. E. and Fitzpatrick, J. W. (1984). The Florida scrub jay: demography of a cooperative-breeding bird. Princeton University Press, Princeton, NJ.

Woolfenden, G. E. and Fitzpatrick, J. W. (1990). Florida scrub jays: a synopsis after 18 years of study. In: Cooperative breeding in birds: Long term studies of ecology and behavior (P. B. Stacey and W. D. Koening, eds.). Cambridge University Press, Cambridge, pp. 241-266.

Zahavi, A. (1990). Arabian babblers: the quest for social status in a cooperative breeder. In: Cooperative breeding in birds: Long term studies of ecology and behavior (P. B. Stacey and W. D. Koening, eds.). Cambridge University Press, Cambridge, pp. 105-130. 